Kohl: a Journal for Body and Gender Research Vol. 3, No. 2 (Winter 2017)

\title{
Clit Intact
}

Naazneen Diwan 
This is the story of my clit intact. Of how I escaped the butcher mother, aunty, family doctor. Of how I sought pleasure, felt pleasure, unflinchingly. Of how pleasure was extracted from my five year old self; how I too am a survivor of patriachy's efforts to cut us down, but not of the knife. This is the story of an almost circumcision and the confusion that surrounds how I was spared. This is part story and part letter because violence never happens in isolation; it is a dialectic. And I exist and survive with some scars and missing others because of all my relations. The only daughter and youngest child. The first born in the U.S. When I was born eight years after my brother, reinforcements were called from India; I let out my first scream with a full head of thick, black hair in October and by November, my Dadi and Jiji had moved in.

I grew up in a household of three watchful mothers. A father who insisted I keep my hair swinging below my waist. An older brother who I never shared a school with and endlessly followed around until he moved out. And still, with all those eyes, they couldn't protect me. Age five was the first time a white boy-soon-to-be-man bullied and lunged at my malleable self-esteem and body. I tried to speak the pain but my family of eyes hadn't yet grown ears adept enough to hear me. It wasn't until I began college that I could string together accusations and they sent me to a psychiatrist. BBC and NPR tell me khatnah is performed from ages 6-8. I wonder, if they had known, would they have vowed to defend me from others' desires and channeled their guilt into slicing apart what he was after? Will our bodies always be found to blame for men's heedless, reckless grasping?

And it is here that the relentless stream of questions takes over. Was it my dad, my ally and best friend, who calmed the scalpel out of their hands? Did not getting cut secure my seat around the kitchen table as an honorary son, one who could talk politics and poetry, enthusiastically sharing my subscription of The Economist and devouring every Khalil Gibran book he lent me? Did the exclusion of the women in my family, one I participated in, make me an agent of patriarchy? Did I help erect a pardah between intact and fractured? Did I enjoy being an exception?

Or was it merely logistical blunders that saved me, the dizzy of new immigrants trying to find ground? Was it because my mom was working 40+ hours a week and taking night classes, and couldn't find a moment to schedule the cutting? Was it that I was born with my father's temper, super strength tantrums, and they didn't have enough people to restrain me? Was it that they knew l'd end up with a trans man, no chance of disgracing them with a pre-marital pregnancy? All I have is speculation, guesses, made-up reasons that diverted me here. With the clit I was born with. Having sex without pain and wondering how and when that became a luxury.

My biggest questions of all are for the women who survived, the ones I never sought out until now because I never knew this practice existed. It wasn't until I was well into my 30's that I found out about khatnah in the Dawoodi Bohra community, ${ }^{2}$ though I didn't need more fuel for my resentment towards the religious leadership. When I read now in media interviews that khatnah is "common," I want to gather and grab all the women that grew me, elders and ancestors, who declared I will inherit this smile,

\footnotetext{
1 Grandmother and Paternal Aunt.

${ }^{2}$ A community that adheres to the Ismaili branch of Shiism and lives in western India, Pakistan, Yemen, and some Eastern African countries.
} 
this gift, all the ones I never met but especially my mother. And the sisters I grew up with who also inherited secrecy, just as I did. Secrecy so tightly woven into our genes that we have to resuscitate our vocal chords to even whisper the truth. Even as I write this, I think of how much I have been told to keep, hold in, and with every sentence I fear I am betraying my family. But it is worse to betray what can heal me - my voice. Women are too good at holding secrets, most of all from each other.

Mothers, was there even a bit of pleasure when you conceived us or did you pray that it would be over quick? Sisters, does it become easier to follow our mothers' orders to clench and tighten our legs, in our foolish hope the wound will one day close? Do you wish it closed and to not exist at all? Does every other part of your body become numb to guard you from the injury that we non-consensually inherited? Are all dangers averted now, after the cutting? Does the woman who strapped you down in her living room, donned gloves and stocked up on gauze, become your pediatrician? Are you forced to call her aunty? Are you saved now from sin and critique or will they find more ways to surveil and charge you? Is this your final punishment or initiation? Do you ask yourself when screaming into your mother's neck and being carried to the car, if this is the consequence for stealing that nail polish from Clare's or refusing to finish the Quran with your dadi? The next week at school, do you wonder if anyone feels the agony of loss oozing from you, a part of you you never fully knew missing? Is it age 25 until you finally look at it again and 27 until you talk about it with sisters of the knife? Do questions ever end their torrent and do any witnesses to the crime against you offer answers to soften the swelling? How has this trespass fortified you for the task and joy of raising your own daughters? Does it ever get easier to forgive?

I couldn't tell the story of my exceptionally loving, enlightened family, because all families love and all families hurt. I love my family and this love can exist in complexity, in disappointment, small and large betrayals, oaths of loyalty that stuff the truth in childhood trunks. Even though they chose to not pass on this tradition to their only daughter, only granddaughter, they did choose to stay in a community that perpetrates and validates misogynistic violence. I could fault them, but what choice were they given by white supremacy: to be ostracized in every direction? We all need some place to belong and sometimes, after traveling continents with blisters and vertigo, we settle in imperfect company.

And there is a mandatory epilogue that must follow. I find it sad that I cannot critique my Bohra Muslim community in peace. Without the fear that predatory Western media and imperialist voyeurs might sample a sound bite to bolster their case against the formerly/currently colonized, the Third World, Islam. I find it sad that Dr. Nagarwala, ${ }^{3}$ who was an adult-sized pawn of patriarchy and misogyny, one that runs deep and can still carry on with one minion down, will be the scapegoat. I am enraged that girls, mostly young, are the ones caught between pious Bohra men and triumphant Western saviors, with neither capable of seeing them as human, as whole.

I don't know what healing looks like but I do know it has nothing to do with the rituals burned into my body when I die or where I'm buried. Maybe healing begins when we cease judging ourselves, blaming ourselves, fixing and measuring ourselves long enough to let maghrib fall in a blaze of magenta and

\footnotetext{
${ }^{3}$ Dr. Jumana Nagarwala, an emergency room physician in Detroit, Michigan, was arrested in April 2017 and charged with practicing FGM, Female Genital Mutilation, on young girls ages 6-9.
} 
Kohl 3.2

crescent moons and jasmine fill in the cracks of our memory. Maybe healing begins with the next generation. Or maybe it begins with this next breath. 